\title{
PARTY AUTONOMY IN LATIN AMERICA: A PENDING TASK
}

\section{LA AUTONOMÍA DE LA VOLUNTAD EN AMÉRICA LATINA: UNA TAREA PENDIENTE}

\author{
María IgnaCia Vial UndurRaga*
}

\begin{abstract}
Party autonomy in international contracts is not statutorily accepted in some Latin American countries where national courts vacillate as to upholding choice of law clauses. The acceptance of autonomy therein is needed to eradicate juridical uncertainty and to harmonize conflict rules within Latin America. OAS' countries drafted The Inter American Convention on the Law Applicable to International Contracts, Mexico 1994 with this objective but it failed to achieve it. Thus, harmonising amendment of the domestic conflict rules on contracts of these countries is pending and might be fostered by a flexible non-binding international instrument that includes rules on autonomy widely accepted in comparative law and respectful of their legal tradition.
\end{abstract}

Keywords: International contracts; party autonomy; governing law of contracts; Latin American conflict rules; "Inter American Convention on the Law Applicable to International Contracts, Mexico 1994".

RESUMEN: La autonomía de la voluntad en los contratos internacionales no está regulada en la legislación de algunos paises latinoamericanos, cuyos tribunales vacilan en aceptar las cláusulas de elección de ley pactadas en ellos. La aceptación de la autonomía en estas legislaciones es necesaria para eliminar la incerteza jurídica acerca de la ley aplicable a los contratos internacionales en Latinoamérica y para armonizar las normas de conflicto que los gobiernan. Los países de la OEA elaboraron la Convención Interamericana de Derecho Aplicable a los Contratos Internacionales, México, 1994 para lograr estos objetivos, pero ella ha fracasado en alcanzarlos. La reforma y armonización de las normas de conflicto sobre contratos está pendiente en estos países y podría promoverse mediante un instrumento internacional flexible y no vinculante que contenga normas reguladoras de la autonomía ampliamente aceptadas en el derecho comparado y respetuosas de su tradición jurídica.

Palabras clave: Contratos internacionales; autonomía de la voluntad; ley aplicable a contratos; normas de conflicto latinoamericanas; Convención Interamericana sobre Derecho Aplicable a los Contratos Internacionales, México 1994.

PhD in Laws, King's College London. Profesora Facultad de Derecho de la Universidad de los Andes. Dirección postal: Monseñor Álvaro del Portillo 12.455, Las Condes, Santiago. Dirección electronica: mivial@ uandes.cl 


\section{INTRODUCTION}

A report requested by the Organization of American States (OAS) in 1988 on the acceptance of the principle of party autonomy in international contracts in Latin America highlighted the importance of harmonizing national laws therein to authorize autonomy ${ }^{1}$. At that moment, Cuba, Mexico and Peru had recently enacted statutory laws broadly authorizing it ${ }^{2}$. Since then Guatemala (1989), Venezuela (1998) Panamá (2014), Dominican Republic (2014), Paraguay (2015) and Argentina (2015), have enacted similar laws but the universal acceptance of autonomy is pending in Latin America ${ }^{3}$. This paper intends to highlight the need for this universal acceptance and to study which are the most suitable tools to achieve it. Thus, it will analyse whether the Inter American Convention on the Law Applicable to International Contracts, signed in Mexico on March 17, 1994 (MC) can consolidate and harmonize conflict rules on autonomy within Latin America; or whether achieving this purpose, will necessarily require harmonising amendment of the domestic conflict rules on contracts of those Latin American countries which now reject, or have no rules on autonomy.

Since a universal coverage of all Latin American countries seems impractical, this study focuses on the acceptance of autonomy in judicial adjudication in three countries, which represent the two main trends as regards the need of consolidation of autonomy in the region. It purposely omits arbitration cases, where autonomy is commonly accepted, subject to the requirements imposed by national arbitration laws.

The selected countries are Brazil, Chile and Uruguay. The reasons for choosing them were several. First, as said, they represent the two main trends as regards the need of consolidation of autonomy in Latin America. Thus, Chile lacks adequate rules to govern autonomy but accepts it as a common legal practice based on a very liberal interpretation of current statues 4 , and Brazil and Uruguay strongly reject it in their laws 5 . Second, some of these countries have had a significant historical legal influence in the conflict laws of Latin America. Thus, the Chilean Civil Code has been adopted and is in force also in Colombia, Ecuador and El Salvador and so what is said about it can be reproduced for these countries. ${ }^{6}$ Besides, this Code has influenced significantly the laws of several other Latin American countries and has contributed to perpetuate the principle of territoriality of laws

See OAS/Ser. 9/93. Similar were the findings in Hague Conference (2008).

2 Art. 17 Cuban Civil Code (CC) (1987), art. 13 V Mexican CC for the D.F. and Federal Matters (1988), art. 2095 Peruvian CC (1984).

3 Art. 2651 Argentinian CC, art. 58 Dominican Republic Private International Law Act (PILA), art. 31 Guatemalan Decree 2-89, Art. 77 Panamanian Code of Private International Law (CPIL), Art. 4 Paraguayan Law 5393, art. 29 Venezuelan PILA.

4 Art. 16 Chilean CC, art. 113 Chilean Commercial Code (CCom), art. 1 Law-Decree 2.349, 1978. See VIAL (2013).

5 Art. 9 Brazilian Introductory Law to the CC (ILCC); art. 2399, art. 2403 Uruguayan CC.

6 The influence of the Chilean CC in Latin America has been considered similar to that of the French Code Civil in Europe, see: GuZmán (1982) p. 468; SAmTleben (1987) p. 163. 
within the region. ${ }^{7}$ And Uruguay has played a major role in the unification of conflict rules within Latin America by contributing to the drafting and enacting of the Montevideo Treaties of 1889 and $1940^{8}$. Third, Brazil has major economic and trade importance in Latin America and, therefore, its laws and economy are fundamental in fostering regional integration in the area ${ }^{9}$.

\section{THE PRINCIPLE OF PARTY AUTONOMY AND ITS ACCEPTANCE IN LATIN AMERICA}

The principle of party autonomy, understood as the right of the parties to choose the governing law of a contract ${ }^{10}$, is accepted almost worldwide ${ }^{11}$ and thus, it is considered to belong to "the common core of the legal systems" 12 but it is not yet universally accepted in Latin American countries ${ }^{13}$. Case law shows that autonomy is, however, regularly practiced in contracts with ties to these countries, including Chile, Brazil and Uruguay where conflict rules either reject it or do not clearly authorize $i t^{14}$. This practice demands an amendment of their conflict rules in order to sanction the exercise of autonomy and set its limits. This seems an urgent task for legislators as current rules on contracts are somehow divorced from legal practice and usages of international trade which widely accept party autonomy.

Nowadays additional techniques are necessary in these jurisdictions to secure the acceptance of a choice of law. The choice of a forum where autonomy is accepted or the submission of the case to arbitration are amongst these techniques but their efficacy is relative since the choice of forum might be challenged and not upheld by courts or the arbitral award might be denied enforcement in a given jurisdiction.

The rejection of autonomy in Latin America has historical reasons. Since colonial times the conflict rules of these countries have been imbued with the principle of territoriality of laws, which precludes applying any law different to that of the forum to acts and contracts made or performed within the forum's jurisdiction. This principle inspired several Latin American early national Civil Codes and continues to be present in some Codes, especially in those that follow the model of the Chilean Civil Code of 1855 . Territoriality was adopted as a tool for promoting and defending national jurisdiction and sovereignty

\footnotetext{
This Code also influenced the CC of Honduras (1880,1906), Nicaragua (1867), Panamá (1860, 1916), Uruguay (1868) and Venezuela $(1862,1942)$ and to a lesser extent the CC of Argentina (1869), Costa Rica (1887), Guatemala (1877) and Mexico (1870, 1928). See GuZmán (1982) pp. 467-468; Samtleben (1979) pp. 182-184; VALLADÃo (1952) pp. 45-53 and (1987) pp. 186, 199-204.

8 FERNÁNDEZ (1994) pp. 97-121.

$9 \quad$ See ECLA (2017) pp. 40, 44.

$10 \quad$ SCOLEs et al. (2004) p. 948; Kassis (1993) p. 187.

11 Hague Conference (2008).

12 Lando (1976) p. 3.

13 Hague Conference (2009) p. 4.

14 De Araujo and Corrêa (2008) pp. 267-280; Albornoz (2009) pp. 631-666; Vial (2013) pp. 896-900.
} 
which could be hindered if foreign laws were allowed to be applied ${ }^{15}$. Because of this, autonomy was and has been rejected as incompatible with this principle. Additionally, autonomy was not mentioned in these early Civil Codes because it was unknown to its authors or rejected by them without further reasoning ${ }^{16}$.

The discussion on the convenience of accepting autonomy in Latin America began while drafting the Montevideo Treaties of 1889. Autonomy, however, was then not adequately understood and rejected on the ground that the governing law of a contract could not be completely determined by the parties since it should always be limited by the public policy of a State ${ }^{17}$. The discussion was reassumed while drafting the Montevideo Treaties of 1940 and autonomy was then rejected in strong terms with the argument of protecting national sovereignty and jurisdiction ${ }^{18}$. This discussion, which had receded since 1940, revived while drafting the MC promoted by OAS; this time autonomy was unanimously accepted by the Inter American drafters who considered it vital for developing international commerce and regional integration ${ }^{19}$. However, their view has not been convincing enough to prevail over the old argument of protecting national sovereignty in countries as Brazil, Chile and Uruguay.

\section{A. The Need of Autonomy in these Jurisdictions}

Party autonomy is justified on several grounds. It recognizes and guarantees contractual freedom for the parties ${ }^{20}$. It permits submitting a contract to a suitable governing law and to exclude inappropriate laws that would govern it in default of choice ${ }^{21}$. It gives certainty and predictability to the parties and diminishes their legal risk as regards the governing law of a contract since parties can anticipate it with accuracy ${ }^{22}$. And it contributes to providing an adequate legal framework for international contracts and, thus, fosters international commerce and economic regional integration ${ }^{23}$. All these reasons justify the authorization of autonomy in Latin America.

\section{Autonomy needed for juridical certainty}

There is a considerable degree of uncertainty on the law governing international contracts and, particularly, on the validity of choice of law clauses, in contracts which have ties with Brazil, Chile and Uruguay. This uncertainty is caused by the diversity of conflict rules on contracts in these jurisdictions, the different degrees of acceptance or refusal of party autonomy in them and the diversity of their case law.

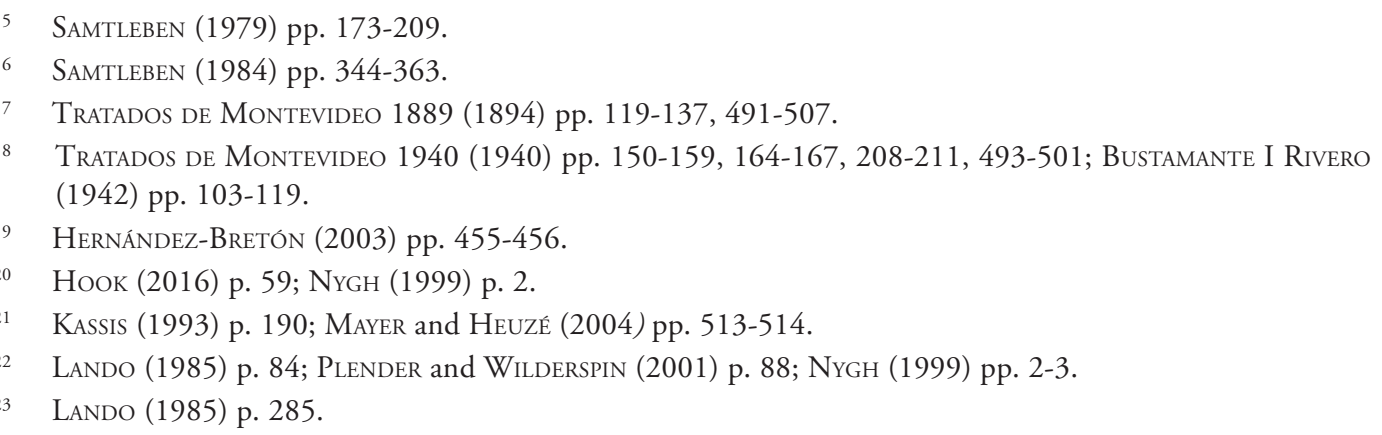


This might be illustrated with the example of a financing contract made in Uruguay between an Uruguayan debtor and an Uruguayan agency of a Brazilian bank. The contract refers to the funding of a construction project in Chile and includes a choice of Brazilian law. In case of breach of this contract, proceedings could be brought either in Brazil, Chile or Uruguay. If they are brought in Uruguay against the creditor or debtor domiciled there, Uruguayan courts would apply the Civil Code and determine that according to the law of the domicile of the debtor at the time of making of the contract, which was Uruguayan law, the choice of Brazilian law is null and, thus, apply Uruguayan substantive provisions on contracts to the contract ${ }^{24}$. If proceedings were brought in Chile, where the construction project is being developed, courts could apply the Commercial Code and uphold the choice of Brazilian law ${ }^{25}$ but could also, in accordance with case law, reject this choice of law by holding that the effects of a contract referring to goods located in Chile are governed exclusively by Chilean substantive law ${ }^{26}$. Finally, if proceedings were brought in Brazil against the Brazilian principal, courts could apply the Introductory Law to the Civil Code to the contract that points to the law of the place of making, Uruguayan law ${ }^{27}$, but could also, according to case law, apply Brazilian law to the contract as the law of its place of performance taking into account that the enforcement of the contract is being pursued in Brazil $^{28}$. Thus, in this latter case, Brazilian courts would not uphold the choice of law clause but would apply to the contract the law chosen by the parties.

The example shows that the diversity of conflict rules on contracts amongst these jurisdictions produces juridical uncertainty as to the law applicable to a contract since this law depends on the forum where the dispute is brought. It also shows that even when countries have conflict rules pointing to the same law, as in the case of Brazil and Uruguay, uncertainty persists since the decision of a particular court might be influenced by national case law pointing to a different governing law. Securing a forum to resolve disputes, however, would not eliminate uncertainty in this case. Thus, if the contract included a choice of the Brazilian, or Chilean, or Uruguayan, forum which was upheld by courts, the determination of the governing law of the contract would still be uncertain due to the differences that exist in each of these jurisdictions between legislation and case law regarding autonomy. Finally, the example suggests that in these jurisdictions the inclusion of a choice of law clause in a contract increases juridical uncertainty as to its governing law due to the lack of clear provisions and case law on the validity of choice of law clauses. This uncertainty seems to be especially increased in Brazil and Chile, where case law tends to apply the law of the forum to international contracts performed in the country notwithstanding the existence of domestic conflict rules pointing to a different law.

The consolidation of autonomy in these jurisdictions would increase juridical certainty as to the governing law of international contracts. This can be seen in the example

\footnotetext{
Art. 2399 Uruguayan CC.

Art. 113 Chilean CCom.

Art. 16 Chilean CC; see also Vial (2013) p. 898.

Art. 9 ILCC.

De Araujo (2002) pp. 201-202.
} 
under consideration. Thus, if autonomy were allowed in these jurisdictions, when proceedings were brought in any of them, courts would uphold the parties' choice of Brazilian law unless there were specific reasons to declare this choice void. Hence, this consolidation, besides increasing juridical certainty for the parties, would lead to a more harmonious case law amongst these jurisdictions.

This juridical certainty for contracting parties is conditional, however, on the acceptance of autonomy in all the jurisdictions connected to the contract. Thus, it would not be guaranteed if autonomy were accepted in only some of the jurisdictions connected to it, since proceedings could be brought in another jurisdiction that rejects autonomy. Thus, the efficacy of autonomy in Latin America would be limited unless it is accepted in all its jurisdictions.

\section{Autonomy needed to harmonize conflict rules}

The domestic conflict rules on the law governing contracts differ significantly amongst the selected countries. Thus, Brazilian law points to the law of the place of making of the contract ${ }^{29}$; Chilean law to either the law chosen by the parties, the law of the place of performance or the law of the place of making of the contract ${ }^{30}$; and Uruguayan law to the law of the place of performance of the contract determined by the irrebuttable presumptions of the Treaty on International Civil Law, Montevideo $1889^{31}$.

This diversity of conflict rules makes it difficult to predict the governing law of contracts with ties to one or several of these jurisdictions. It also increases legal risks for the parties since courts might apply to a contract a law that was never foreseen by them, as Chilean law in the example given above. Finally, it might increase the legal cost of an international transaction since the drafting of the contract or the determination and proof of the applicable law might demand specialized and costly legal assistance. These unfortunate effects need to be corrected to foster international and cross-border transactions between these jurisdictions and to secure a fair transaction between the parties. Thus, they might affect and damage, especially, the weaker party to a transaction, such as the consumer or small producer, who might not have access to the legal expertise to prevent them. The consolidation of autonomy in these jurisdictions would contribute to harmonizing conflict rules on contracts and to diminishing legal risks and costs in respect of them.

Harmonizing conflict rules on autonomy is especially needed in those Latin American countries intending economic integration in a common market such as the MERCOSUR customs union. Amongst these countries, only Argentina, Paraguay, Peru and Venezuela have rules broadly authorizing choice of law clauses. It is reasonable to suppose that the number of contracts containing these clauses and of judicial cases in respect of them will increase with the growth of cross-border transactions fostered by the MERCOSUR. This might move parties to engage in "forum shopping" in order to begin or avoid proceedings in those jurisdictions that accept or reject autonomy, in accordance with their

29 Art. 9 Brazilian ILCC.

30 Art. 113 Chilean CCom; art. 16 CC.

31 Art. 2399 Uruguayan CC; arts. 34-38 Treaty on International Civil Law, Montevideo 1889. 
best interests. Thus, to prevent this "forum shopping" and to anticipate more easily the law which will be applied to international contracts within the MERCOSUR, it would be convenient that autonomy is consolidated in similar terms in all the member countries so that the chosen law is applied irrespective of the country in which a judgment is given ${ }^{32}$. This would secure the effective integration of the members of MERCOSUR and would provide them with the appropriate contractual legal framework for the functioning of their future common market ${ }^{33}$. A similar rationale can be applied to other Latin American associations intending economic integration such as ALADI (Latin American Association of Integration), CAN (Andean Community of Nations) and the Pacific Alliance.

Besides, the consolidation of autonomy in the selected countries would contribute to harmonizing their conflict rules with their rules on arbitration, which permit upholding choice of law clauses ${ }^{34}$.

This consolidation, though an important step towards harmonizing conflict rules in Latin America will, however, have a limited effect in guaranteeing juridical certainty if not supplemented by the harmonization of the default rules on the law governing international contracts in the absence of choice by the parties. The additional harmonization of these default rules would allow parties to anticipate this law with reasonable certainty in any Latin American fora.

\section{Autonomy needed to guarantee a suitable law for an international contract}

Autonomy allows parties to choose, with flexibility, a suitable law to govern their contract. This flexibility would allow parties to opt out of Brazilian and Chilean conflict rules pointing to the law of the place of making to govern a contract, or the law determined by the irrebuttable presumptions of the Treaty on International Civil Law of Montevideo, 1889 in Uruguay, when these laws have no substantial ties with the contract or seem unsuitable to govern $\mathrm{it}^{35}$. It would also counteract the Brazilian and Chilean judicial trend to apply their national laws to international contracts even when a contract has little connection to them ${ }^{36}$.

Thus, the consolidation of autonomy in Brazil, Chile and Uruguay seems necessary to fulfil these three needs.

\section{ANALYSIS OF THE POSSIBLE ROUTES FOR THE CONSOLIDATION OF AUTONOMY IN LATIN AMERICA}

Two routes are to be analysed: the ratification of the MC and the amendments of the conflict rules of those countries, which have no rules on autonomy. Both are relevant

\footnotetext{
32 This same reasoning led to the drafting of the Rome Convention, 1980 which consolidated autonomy in the EU: Giuliano and Lagarde (1980) pp. 4-5.

33 Art. 1 Treaty for the Constitution of Mercosur, Asunción 1991; Feldstein (2000) pp. 361-362, 376-377.

34 Brazilian Law 9.307 of 1996; Chilean Law 19.971 of 2004; Uruguayan General Procedural Code of 1988.

35 Art. 9 Brazilian ILCC; arts. 14, 16 Chilean CC; art. 2399 Uruguayan CC.

36 See for Brazil, Araujo (2002) p. 202; Griffith (1959) p. 55 and for Chile, Vial (2013) pp. 896-900.
} 
since a) the $\mathrm{MC}$ was drafted by the OAS to harmonize conflict rules on contracts within Latin America and b) the amendment of the conflict rules of these countries has been attempted several times by national legislators as a necessary measure for obtaining this harmonization.

OAS countries have explored two further routes with limited success. First, the adoption of the United Nations Convention on Contracts for the International Sale of Goods, 1980 (CISG) ${ }^{37}$ which is in force in 14 Latin American countries and has harmonized laws in respect of these contracts but, has consolidated only a limited acceptance of autonomy therein by restricting the parties' choice to the possibility of derogating from its rules $^{38}$. And second, the ratification of the The Hague Convention on the Law Applicable to Contracts for the International Sale of Goods, 1986 but only Argentina has become a party to this convention which is not yet in force ${ }^{39}$.

\section{A. The Mexico Convention, 1994 Conceived as a Tool for the} Consolidation of Autonomy in Latin America

The OAS focused on drafting Inter American conventions on conflict issues to be approved in specialized conferences, known as $\mathrm{CIDIP}^{40}$. As to autonomy, the MC signed on 17-III-1994 at CIDIP V is mostly relevant, since it is the first Inter American Convention broadly authorizing autonomy.

The drafting process of the MC shows that the consolidation of autonomy within Latin American countries seemed paramount to OAS' States to develop regional integration and foster international trade ${ }^{41}$. It was agreed by them that an international convention was the appropriate tool to achieve this consolidation. Further, this view was shared even by those States that do not accept autonomy in their domestic conflict rules, such as Brazil and Uruguay, which were amongst the signatories of the MC. This consensus has led paradoxically, to only five signatures and two ratifications of the $\mathrm{MC}$ and it is doubtful that more countries are to sign or ratify it in the future ${ }^{42}$.

The degree of acceptance of party autonomy in Latin American countries has changed little after the MC was drafted. They keep, with the exception of Venezuela and more recently of Argentina, Paraguay and Dominican Republic almost the same rules to govern international contracts that were in force prior to the MC.

The MC, however, has had some positive influence in the development of conflict rules on contracts in Latin America. It has inspired the Venezuelan Private International Law Act (1998), the Dominican Republic Private International Law Act (2014), the Para-

\footnotetext{
37 CIDIP IVIRes. 2/89.

38 Art. 6 CISG.

39 See Boggiano (1993) and OAS/Ser. 10/93.

40 See http://www.oas.org/es/sla/ddi/derecho_internacional_privado.asp. Date of visit 27 December 2017 and SAmtleben (1983) pp. 35-44.

${ }^{41}$ On the genesis of the MC see: OEA/Ser. 11/93 pp. 17-18; Garro (1992) pp. 587-616; Herbert (1994) pp. 45-62; Juenger (1994) pp. 381-393; Parra-Aranguren (1994) pp. 179-247 and (1996) pp. 299-320.

42 The MC entered into force between Mexico and Venezuela on 15 December 1996. Other signatories are Bolivia, Brazil and Uruguay.
} 
guayan Law 5393 on the Law Applicable to International Contracts (2015) and some draft bills in Brazil ${ }^{43}$ and Uruguay ${ }^{44}$. Besides, it has also reflected an OAS official policy towards promoting the harmonization of conflict rules on contracts and the consolidation of autonomy within its member States ${ }^{45}$. Thus, the importance of the MC consists in having been used as a model for drafting domestic conflict rules, rather than in its actual implementation within Latin America.

\section{The MC: relevant features in respect of autonomy}

The acceptance of autonomy is the main feature of the $\mathrm{MC}^{46}$. Only in the absence of the parties' choice or when this choice is ineffective, other default laws apply to the contract $^{47}$. Autonomy is accepted with very few limits and in wide terms for international contracts -civil and commercial- within the scope of the $\mathrm{MC}^{48}$. Thus, parties are allowed to choose or change the law applicable to the contract at any time, to split this law or to choose the law of a State not connected to it or of a State not party to the MC ${ }^{49}$. The choice of law by the parties might be express or tacit ${ }^{50}$. The scope of the chosen law is wide $e^{51}$ and its application is limited only by the public policy and the mandatory rules of the forum and, discretionally, by the mandatory rules of another State connected to the contract $^{52}$. In all these aspects the MC follows closely the Convention on the Law Applicable to Contractual Obligations, 1980 which was its model.

The MC is not applicable to purely domestic contracts and to those contracts excluded by a declaration of a State Party when ratifying or acceding to $i^{53}$. Likewise, the MC does not limit autonomy in certain types of contracts where the weaker party might need protection $^{54}$, though State parties might declare these contracts excluded from its scope ${ }^{55}$. And the MC assigns a role to the lex mercatoria in governing contracts. Thus, it states that "the guidelines, customs and principles of international commercial law as well as commercial usage and practices generally accepted shall apply in order to discharge the requi-

\footnotetext{
43 Projeto de Lei $\mathrm{N}^{\circ}$ 4.905, 1995 shelved in 1996 and Projeto de Lei do Senado No 269, 2004 shelved in 2010.

44 The Uruguayan Bills for a General Law of Private International Law, 2004 (shelved in 2005) and 2009 (still under discussion by Parliament).

45 See OAS CP/Res. 486 (717/87); Hernández-Bretón (2003) pp. 454-456; Posenato (2006) p. 22.

46 Art. 7 MC.

47 Art. 8 MC.

48 Arts. 1, $3 \mathrm{MC}$. The $\mathrm{MC}$ applies to unilateral acts connected with a contract: OEA/Ser. 32/94 rev. 1, p. 1 and OEA/Ser. 46/94, vol. 2, pp. 6-8.

49 Arts. 2, 7-8 MC.

50 Art. 7 MC.

51 Arts. 12-14 MC.

52 See arts. 11, 18 MC. The MC gives no guidelines to courts on the discretionary application of the mandatory rules of the law of a third State connected to the contract.

53 Art. $1 \mathrm{MC}$.

54 This limit was never discussed or included in any drafts of the MC, see OEA/Ser. 10/93; OEA/Ser. 12/93; OEA/Ser. 15/93; OEA/Ser. 14/93.

55 Arts. 1, 11, 18 MC. See Juenger (1997) p. 204.
} 
rements of justice and equity in the particular case" ${ }^{256}$. Besides, in the absence of choice of law by the parties, the MC refers to a need "to take into account the general principles of international commercial law recognized by international organizations" along with other elements of the contract to determine the law that is to govern $i t^{57}$.

There is no doctrinal consensus, however, as to the possibility under the $\mathrm{MC}$ that the lex mercatoria becomes the proper law of the contract when chosen by the parties ${ }^{58}$. Neither its text, nor the history of its drafting, provides a clear answer to this problem ${ }^{59}$. Some doctrine construes the $\mathrm{MC}$ as stating that the governing law of a contract shall always be the law of a State ${ }^{60}$. Accordingly, the principles of international commercial law and the lex mercatoria are to serve as auxiliary guidelines for determining the law of the State most closely connected to the contract in the absence of choice of law by the parties, or are to supplement this law when needed, but are not to replace it as the governing law of the contract ${ }^{61}$. Other doctrine, more solidly grounded, argues that the $\mathrm{MC}$ permits the parties to choose the lex mercatoria to govern a contract. It argues that if the MC permits courts to apply these "principles of international commercial law" to govern a contract in the absence of choice of law by the parties or "the guidelines, customs and principles of international commercial law as well as commercial usage and practices generally accepted" when equity requires it, it is coherent to conclude that it also allows parties to make them applicable to a contract by choosing them ${ }^{62}$. In sum, though the MC is ambiguous in its reference to the lex mercatoria; it seems that it is inclined to accept choices of this law by the parties ${ }^{63}$.

\footnotetext{
56 Art. 10 MC. See Nygh (1999) p. 66.

57 Art. 9 MC.

58 Juenger, the USA delegate, who proposed including the reference to the general principles of international commercial law in art. $9 \mathrm{MC}$, argues that the MC allows choices of the lex mercatoria and so does Parra-Aranguren who was the drafter of art. 10 MC. See Juenger (1997) pp. 204-205 and (1994) pp. 391-392; PARRA-Aranguren (1994) pp. 218-220 and (1996) pp. 308-309. Endorsing their opinion see Hernández-Bretón (2005) pp. 5-7; Nygh (1999) pp. 62, 187-188; Pereznieto and Silva (2000) pp. 283-284; Samtleben (2002) pp. 365-370. Against their opinion see Boggiano (1996) pp. 224-226 and (1995) pp. XXVII-XXIX; FernánDEZ (1995) pp. 182-183; Herbert (1994) pp. 53-54; LANDO (1996-97) pp. 63-64; SANTOS (1998) pp. 91-92.

59 Art. 9 was the fruit of a compromise between the USA proposition of applying the UNIDROIT principles on contracts as governing law of a contract in default of choice by the parties and those opposing this view. Art. 10 was approved stating that the lex mercatoria was to supplement the governing law of a contract when demanded by equity. However, the report of the Tucson meeting, where this provision was drafted, highlights that the intention of some experts was to include the lex mercatoria in the $\mathrm{MC}$ as the principal source of law for international contracts. See the discussions held in CIDIP V in OEA/Ser. 46/94, vol. 2, pp. 46-50, 58-61; OEA/ Ser. 46/94, vol. 1, pp. 24-29; OEA/Ser. 32/94 rev., p. 3. See the discussions held in Tucson in OEA/Ser. 14/93, pp. 3, 8-9, 16-17, 28-29.

60 Boggiano (1996) pp. 224-226; Fernández (1995) pp. 182-183; Herbert (1994) pp. 53-54; Lando (1996-97) pp. 63-64.

61 See Noodt (1997) pp. 103-104.

62 Arts. 9-10 MC. Hernández-Bretón (2005) pp. 5-7 and (2001) p. 333; Juenger (1997) pp-204-205 and (1994) pp. 384, 392; Nygh (1999) pp. 62, 187-188; Parra-Aranguren (1996) pp. 308-309; Pereznieto and Silva (2000) pp.283-284; Samtleben (2002) pp. 365-370.

63 Nygh (1999) pp. 62, 187-188; Samtleben (2002) pp. 354-371.
} 


\section{The failure of the $M C$ in consolidating autonomy in Latin America}

There are several reasons that could explain the failure of the $\mathrm{MC}$ in consolidating autonomy in Latin America ${ }^{64}$. They merit to be analysed in order to correct them in new attempts of consolidation.

These reasons refer to a deficiency of the MC itself, namely, its restricted scope of application; and to deficiencies in the legal systems of Latin American countries, such as, the need for supplementing the MC with an adequate set of domestic conflict rules, currently inexistent, and its conflict with the legal tradition of some countries, reluctant to introduce changes in their legislation.

\section{a) The limited scope of application of the $M C$}

Article 1 of the MC fixes its scope of application when stating that this Convention shall determine the applicable law to international contracts. This wide scope of application is, however, only apparent since it is restricted by the requirement that the contract be linked to two or more State parties to the MC.

This restriction, though not expressed in the text of the MC, can be inferred from the characterization of an international contract included in it, which reads as follows: "a contract is international if the parties thereto have their habitual residence or establishments in different State Parties or if the contract has objective ties with more than one State Party" (art. 1 par $2^{\text {nd }}$ ). As a consequence, the MC only applies to contracts which fulfil these requisites ${ }^{65}$. Hence, international contracts whose parties have their habitual residence or establishments in different States which are not party to the MC, international contracts where one party resides in a State party and the other resides in a State not party to the $\mathrm{MC}$ and international contracts that have objective ties with only one State party to the $\mathrm{MC}$ are outside its scope.

Thus, where the MC is enacted, international contracts are necessarily submitted to a double legal regime: that of the MC, for contracts under its scope, and that of other conflict rules -domestic or international-, for all other contracts, which might outnumber those governed by the MC. This double legal regime will make the acceptance of autonomy limited and exceptional in those enacting States where domestic conflict rules reject autonomy or will provide different solutions in respect of autonomy if enacting States have conflict rules which are not in harmony with the MC. Hence, the lack of universality of the $\mathrm{MC}$ makes it unable to consolidate autonomy or to establish uniform rules to govern international contracts within or between the State parties to it. Moreover, by multiplying conflict rules the MC increases juridical uncertainty in respect of the law governing contracts in these States. Consequently, even if the MC were enacted in all Latin American States, the problem of guaranteeing the acceptance of autonomy and of achieving uniform rules to govern contracts therein would persist, unless they enact other conflict rules in harmony with those of the MC. This conclusion is more evident when taking into account

\footnotetext{
64 Few authors comment on the reasons for the lack of ratifications of the MC but fail to analyse them: HernándeZ-Bretón (2003) pp. 441-471; Posenato (2006) p. 62.

65 Fernández (1995) pp. 181-182; Leyva (1998) p. 321; Noodt (1997) pp. 128-129.
} 
that contracts with ties to important commercial partners to Latin American States, such as European and Asian States, are outside the scope of the MC and, therefore, will normally be governed by domestic conflict rules ${ }^{66}$.

Limiting the scope of application of the MC to contracts linked to at least two State parties, does not reconcile well with the logic of granting the parties the right to choose the law of States not parties to the $\mathrm{MC}^{67}$ or with the extreme liberality of entitling them to choose the lex mercatoria to govern a contract ${ }^{68}$. It is, for example, paradoxical that the choice of German law in a contract between companies of two State parties would be upheld and governed by the MC and a contract between a company of a State party and a German company containing the same clause would be governed by different provisions which could uphold it or not. It seems that this exclusion diminishes the consistency of the MC which, while allowing party autonomy in ample terms restricts, at the same time, its scope of application significantly.

The rationale for restricting the scope of application of the MC to contracts involving Latin American ratifying States is difficult to identify from the documents that give the account of its drafting process. This restriction does not appear to have been thoroughly discussed at any stage of this process. The first draft of the MC, the CJI Draft, influenced by the Rome Convention, did not contain this restriction and intended the MC to be applied universally, to all international contracts within the State Parties ${ }^{69}$. This draft was changed in a meeting of experts held in Tucson with the consequence of restricting the scope of application of the future MC. There, the discussion focused on the convenience of restricting autonomy to international contracts ${ }^{70}$. With this purpose, a specific characterisation for these contracts was included in art. $1^{71}$. The experts, however, do not appear to have taken into account that the new characterisation restricted substantially the scope of application of the MC, nor did they measure the effects that this restriction could have in

66 See trade data in FITA: www.fita.org/countries. Date of visit: 27 December 2016; and SICE: www.sice. oas.org/countries_e.asp. Date of visit: 27 December 2017. This data shows that trade with non Latin American countries represents an important percentage of their trade exchange; thus, the number of contracts not governed by the MC might outrank in number those governed by it.

67 Art. 2 MC.

68 Arts. 9-10 MC.

69) See CJI Draft in OEA/Ser. 12/93.

Art. 1 reads as follows:

"The provisions of this Convention shall be applicable to situations that involve conflict of laws in respect of contractual obligations of a private nature.

The international nature of the contract must be evident from objective elements located in various States.

The law designated by the Convention shall be applied even if the said law is that of a State that is not a party"

70 The spatial application of the MC was not discussed. See the report of the meeting in OEA/Ser. 14/93, pp. 7, 10, 21 and the Tucson Draft in OEA/Ser. 15/93.

71 Art. 1 of the Tucson Draft reads as follows:

"This Convention determines the law applicable to international contracts.

A contract is international when the parties have their commercial establishments in different State Parties, or when the contract has objective contacts with more than one State Party.

This Convention shall not apply to contracts between States or to contracts of a public nature where the State or a State agency or entity is party." 
respect of its efficacy. This restriction was not discussed either by the delegates to CIDIP V when approving the final text of the $\mathrm{MC}^{72}$. Similar oversight about the effects of this restriction can be found in literature commenting on the $\mathrm{MC}^{73}$.

This restricted scope of application reduces considerably the efficacy and attractiveness of the MC and might deter States from ratifying it. Multiplication of conflict rules and increasing overlapping of provisions, either domestic or international, make it more difficult for courts, legal practitioners and traders to determine or predict which is to be the law governing a contract and so can only doubtfully help to foster international commerce or eliminate barriers for cross-border transactions. Further, predicting that a contract is to be governed by the $\mathrm{MC}$ is a task not without difficulty. The $\mathrm{MC}$ gives great discretion to courts for determining the existence of the elements to characterize a contract as international for the purpose of fixing its scope of application. Thus, the MC leaves to national courts the power of determining when a party has its residence in a State party or which elements of a contract can be considered as objective ties to a particular State party, both being fundamental determinations in deciding whether the MC applies to a contract ${ }^{74}$. Consequently, parties cannot have complete certainty that a contract is to be governed by the MC until courts have so determined, uncertainty that can hardly be considered ideal to promote regional trade or to avoid forum shopping.

\section{b) The need to supplement the MC with an adequate set of conflict rules}

The implementation of the MC requires that every State party has adequate conflict rules to supplement it when the MC refers certain issues to national laws or leaves legal gaps to be filled in. These rules are equally needed for contracts outside its scope of application. Conveniently, these conflict rules should provide solutions in harmony with those of the MC so as to secure juridical certainty and predictability ${ }^{75}$. However, these rules on autonomy do not currently exist in Brazil, Chile and Uruguay. Thus, these countries will need to amend their conflict rules prior or subsequent to ratifying the MC in order to implement it. But several attempts to introduce necessary amendments in some of them have failed. Meanwhile, the lack of these conflict rules acts as a positive deterrent to the ratification of the MC by these countries.

This situation can be illustrated when analysing Chilean law. This law has no domestic provisions to determine whether courts must apply foreign law ex officio or whether it must be proved by the parties in the case, or for providing for the protection of the public policy of the forum and the fulfilment of Chilean mandatory rules, or for determining

\footnotetext{
72 See the report of the rapporteur in OEA/Ser. $32 / 94 \mathrm{rev} .1$ and Minute of the plenary session of CIDIP-V in OEA/Ser. 46/94, vol 1, pp. 20-21.

73 Burman (1995) p. 380; De Maeklt (2001) p. 374; Hernández-Bretón (2005) p. 3; Lucas (1996) pp. 132-133; Herbert (1994) pp. 48-51; Juenger (1994) pp. 381-393 and (1997) p. 204; Opertti (1994) pp. 28-30; Parra-Aranguren (1994) pp. 205-206, 214-215 and (1996) pp. 305-306; Posenato (2006) pp. 30-46; SANTOS (1998) Ch. 1-10. A slight reference to this restriction is made by ReCHSTEINER (2002) pp. 140-141.

74 Art. 1 MC. See OEA/Ser. 14/93, p. 14.

75 For instance, when determining the indicators of a tacit choice of law or the limits for exercising autonomy: arts. 7, 11, $18 \mathrm{MC}$.
} 
criteria to solve an issue of characterisation ${ }^{76}$. Thus, when the $\mathrm{MC}$ requires the application of a foreign law to a contract, either because the parties have chosen it or, because it has been determined by the rules of the MC, Chilean law has no clear criteria to determine how the provisions of that foreign law shall be applied or which are the limits to which they are to be subjected. Hence, Chilean law lacks provisions that are essential to supplement and enforce the MC.

A similar lack of provisions to supplement adequately the MC can be observed in Brazilian and Uruguayan law. Though both legal systems have a more developed conflict system than that of Chilean law, they reject autonomy in clear terms and can hardly be reconciled or harmonized with the provisions of the MC. This rejection of autonomy leads one to wonder whether the protection of the public policy or mandatory rules of the forum will be used by courts to declare inapplicable provisions of the MC conflicting with those of the forum. For instance, those submitting certain contractual issues to the chosen law when a mandatory rule submits them to the law of the place of making in Brazil, or to the law of the place of performance in Uruguay ${ }^{77}$. Thus, unless these laws are amended to accept autonomy, the ratification and enforcement of the MC will remain uncertain in these countries.

In addition, the lack of provisions on international contracts in national laws might also be a positive deterrent to ratifying the MC if considering that it allows parties to choose the lex mercatoria to govern a contract. The incompleteness of this lex mercatoria makes having recourse to the law of the forum for supplementation more necessary than when choosing a State law and thus, adds another reason to oppose ratifying the MC while or if domestic conflict rules are not amended having in mind this need.

This problem seems to have been understood by the Venezuelan legislator who, after enacting the MC, enacted the 1998 Private International Law Act, purposely modelled on the $\mathrm{MC}$ so as to harmonize domestic conflict rules with its provisions. Similar procedures will need to be followed by other countries when enacting the MC.

\section{c) Conflict between the $M C$ and the legal traditions of certain countries}

The authorization of autonomy in the MC conflicts with the legal tradition of the selected countries to different degrees. This opposition is strong in Brazil and Uruguay, who reject autonomy in their conflict rules. It is less strong in Chile where autonomy is widely practiced notwithstanding that conflict rules authorize it restrictedly and case law tends to apply Chilean law to contracts linked to the country.

Legal tradition, national pride and significant divergence between the laws intended to be harmonized are well known obstacles to harmonization of laws amongst countries ${ }^{78}$. All of them are present to a certain extent in Brazil, Chile and Uruguay and can hinder their ratification of the MC. Thus, the weight of legal tradition in these countries and an excessive respect for the provisions of the old Civil Codes have contributed to a long

76 Villarroel and Villarroel (2015) pp. 69, 98-100, 144-145.

77 Art. 9 Brazilian ILCC; art. 2399 Uruguayan CC.

78 Parra-Aranguren (1988) pp. 39-57. 
standing reluctance of national legislators in amending domestic conflict rules and, more recently, in ratifying the international conventions elaborated within the various CIDIP $^{79}$.

A preliminary and overall analysis of Brazilian, Chilean and Uruguayan legal situation shows that the MC, which was welcomed with enthusiasm by doctrine ${ }^{80}$, has failed to enthuse national legislators. These legislators have shown themselves unconvinced, not only of the need of ratifying the $\mathrm{MC}$, but also of that of changing the conflict rules on contracts in these jurisdictions.

This is the case in Brazil whose government, after having signed the MC in 1994, has not asked Parliament to ratify it. This omission seems to conform to a subsequent change of policy towards autonomy and the convenience of amending national conflict rules to authorize it. Thus, the government withdrew in 1996 a bill intending to harmonize domestic conflict rules with those of the $\mathrm{MC}^{81}$ and replaced it in 2002 by another bill ${ }^{82}$ that opposed autonomy and was incompatible with the provisions of the MC. Another bill accepting autonomy was presented to Parliament in $2004^{83}$ but was shelved in 2011 together with the 2002 bill. It seems that the Brazilian legislator does not intend to ratify the MC or to change the provisions of the Introductory Law to the Civil Code (1942) opposing autonomy. However, it is possible, though still uncertain, that the legislator will overcome its reluctance to accept autonomy as influenced by doctrine, some recent case law and an increasing recognition of the parties' role in determining the law applicable to international contracts in arbitral proceedings ${ }^{84}$.

In Uruguay, the historical opposition to autonomy comes accompanied by a strong national pride in the provisions of the Montevideo Treaties 1889-1940, which the country helped to draft, and which have been applied widely since 1941 when they were incorporated into the Civil Code ${ }^{85}$. The Uruguayan government signed the MC in 1994 and sent to Parliament in 1995 a bill proposing its ratification, which, after several years of discussion, was shelved in February, 2005 ${ }^{86}$. Another bill, the Bill for a General Law of Private International Law, 2004 which intended to amend the provisions of the Civil Code and accept autonomy was shelved in February, 2005 but replaced by another in 2009, still under discussion, which proposes a more restricted acceptance of autonomy ${ }^{87}$. All this shows that the legislator is hesitant as to accepting autonomy. Further, national doctrine, though progressively supportive of autonomy ${ }^{88}$, has been critical of the MC. It has criticized as

\footnotetext{
79 See:http://www.oas.org/es/sla/ddi/docs/derecho_internacional_privado_resumen_estado_firmas_ratificaciones.pdf. Date of visit: 27 December 2017. See also FernÁndez (1994) pp. 197, 202, 206-207.

80 Boggiano (1995) pp. VII-XXXI; De Araujo (1998) pp. 455-457; León (2002) pp. 188-189.

$81 \quad$ Projeto de Lei 4.905, 1995.

82 Projeto de Lei do Senado 243, 2002.

83 Projeto de Lei do Senado 269, 2004.

84 Art. 2 Law 9307 of 1996; De Araujo and Corrêa (2008) pp. 267-280; Reichsteiner (2002) p. 139; Strenger (1996) pp. 679-680 and (1967) pp. 204-205; VAlladāo (1974) pp. 353-354.

85 Law 10.084 of 1941.

86 See https://parlamento.gub.uy/documentosyleyes/ficha-asunto/25313. Date of visit: 10 January 2018.

87 See https://parlamento.gub.uy/documentosyleyes/ficha-asunto/38377. Date of visit: 10 January 2018.

88 Santos (1998) pp. 71-72; Opertti and Fresnedo (1997) p. 55; Opperti (1994) p. 28.
} 
excessive the discretion granted to courts to determine the governing law of a contract in the absence of choice by the parties ${ }^{89}$. This criticism seems to have had some influence on the Bills for a General Law of Private International Law, 2004 and 2009 which instead of adopting the default rules of the MC, adopts the provisions of the Treaty of International Civil Law of Montevideo, $1940^{90}$. These proposals also show that the national legislator is reluctant to depart totally from the traditional Montevideo Treaties' provisions even if approving autonomy.

Though autonomy is not a complete novelty in Chilean legal tradition, ratifying the $\mathrm{MC}$ would mean abandoning -at least for the contracts under its scope- the territorialism that inspires the Civil Code's conflict rules ${ }^{91}$. Thus, contracts to have effect in Chile will no longer be mainly governed by Chilean law but by the law determined by the MC. This raises the question as to whether courts will apply this law without an amendment of the Civil Code rules which have normally been construed as overriding any other governing law of a contract ${ }^{92}$. Hence, it is difficult to predict as to what extent courts will decide that mandatory rules of the forum or the protection of its public policy will limit the application of the MC in contracts to be performed in Chile.

In sum, preserving legal tradition weighs against amending national conflict rules and ratifying the $\mathrm{MC}$ in these jurisdictions.

\section{Prospect of future ratifications of the MC by the selected countries}

The prospect of future ratifications of the $\mathrm{MC}$ can be further analysed taking into account additional factors.

A preliminary view shows that the number of countries which have signed the MC contrasts sharply with the number of countries that had previously expressed interest in enacting it. Thus, only five countries signed the MC -Bolivia, Brazil, Mexico, Uruguay and Venezuela- of which only two have ratified it; whereas, sixteen countries intervened in its drafting ${ }^{93}$. This small number of ratifications is symptomatic of the attitude that Latin American countries have had regarding different attempts to harmonize laws.

Thus, Latin American Countries have been criticized for their longstanding "passive resistance" to the adoption of uniform rules ${ }^{94}$. This resistance seems to be being exercised in respect of the MC: though it enthused doctrine, it has not moved legislators to take steps to adopt it. This is the case in Chile who has not signed the MC or expressed any official interest of acceding to it. Besides, a clear decline of the initial interest in ratifying it can be observed in Brazil and Uruguay.

\footnotetext{
Opertti and Fresnedo (1997) pp. 35-37; Santos (1998) pp. 128-133.

Art. 47 Uruguayan Bill, 2004; art. 45 Uruguayan Bill, 2009.

Arts. 14, 16 Chilean CC; art. 113 Chilean CCom; ViAL (2013) pp. 895-900.

VIAL (2013) pp. 898-899.

Argentina, Bolivia, Brazil, Canada, Mexico, Panama, Paraguay, Peru, Nicaragua, Uruguay, USA and Venezuela participated in the drafting of the MC, see OEA/Ser. 46/94. Chile, Colombia, Costa Rica and Honduras had encouraged its drafting, see OEA/Ser. 11/93, pp. 56, 68, 116, 171.

94 See Parra-Aranguren (1988) p. 54.
} 
A country by country analysis of the removal of legal obstacles needed to enact the $\mathrm{MC}$ shows that the selected countries need substantial legal amendments to implement it.

In Brazil, the law in force rejects autonomy and contains mandatory rules referring contracts to the law of their place of making ${ }^{95}$. The mandatory character of these provisions makes them prevail over those of international treaties in force. Thus, unless Brazil amends them to accept autonomy, the MC, even if ratified by Parliament, could not possibly be implemented in those aspects that conflict with actual legislation. In this respect, two bills, Projeto de Lei 4.905, 1995 and Projeto de Lei de Senado No 269 of 2004 proposed conflict rules that would have harmonized domestic law with the MC but both bills were rejected ${ }^{96}$. Seemingly, the Brazilian legislator has abandoned its interest in ratifying the MC.

Chilean law lacks provisions that are essential to supplement and enforce the $\mathrm{MC}^{97}$. Further, case law tends to apply Chilean law to contracts that are to have effect or are to be performed in Chile due to the strong territorialism that inspires Chilean law ${ }^{98}$. Thus, implementation of the MC will require the enactment of new general conflict rules and specific conflict rules on contracts. Further, mandatory conflict rules that provide for the application of the law of the place of making and the law of the place of performance for contractual issues should be replaced by more flexible conflict rules that guarantee greater freedom to contracting parties. Without these amendments -of which there is no proposalenacting the $\mathrm{MC}$ would be ineffective.

Uruguayan doctrine has stated that enacting the MC would mean a radical change in Uruguayan conflict rules and the withdrawal of a legal practice adopted for more than a century ${ }^{99}$. This statement highlights the strong disagreement between the MC and the Uruguayan conflict rules and case law. Thus, autonomy has been consistently considered by courts as contrary to Uruguayan law and public policy. Because of this, the acceptance of autonomy in Uruguay requires, necessarily, amendments of the domestic rules on the law governing international contracts ${ }^{100}$. Without these amendments autonomy would be accepted only in contracts governed by the $\mathrm{MC}$ and would continue to be rejected in all other contracts. The Bill for a General Law of Private International Law, 2009 proposes these amendments. It remains to be seen whether it will be enacted as law or will be rejected, as a similar bill was in 2005 .

Thus, legal tradition is a real obstacle to enacting the MC in these countries. Strong political and juridical will seem to be needed to overcome this obstacle and to change conflict rules on contracts in these jurisdictions. At present, national legislators seem not fully convinced of the convenience of this change and, so, the ratification of the $\mathrm{MC}$ by these countries seems unlikely. The same applies to the incorporation of its rules into their do-

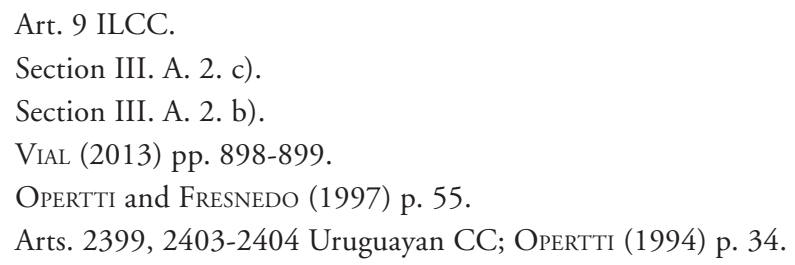


mestic conflict rules or to the ratification of a new and perfected convention that accepts autonomy universally which could not possibly be implemented without further amendments of their domestic conflict rules.

In sum, it seems that the consolidation of autonomy and harmonization of rules on international contracts can be more effectively achieved in Latin American countries by the amendment of their domestic conflict rules on contracts that incorporates rules widely accepted in comparative law. Further, it seems that the ratification of the MC might follow these amendments but will not be the principal cause to produce them. National legislators might be moved to make them by the lobby of national legal practitioners who are increasingly including choice of law clauses in international contracts and courts who are beginning to accept these clauses in some cases, albeit with a vacillating case law. International organizations and scholars could contribute to this lobby with comparative studies that highlight the convenience of adopting harmonious rules on autonomy and give suggestions as to the possible mechanisms to avoid abuse of it.

\section{THE AMENDMENT OF THE CONFLICT RULES ON CONTRACTS OF BRAZIL, CHILE AND URUGUAY IN ORDER TO CONSOLIDATE AUTONOMY AND HARMONIZE LAWS IN LATIN AMERICA}

The problem that remains to be solved is how to foster a harmonious amendment of the domestic conflict rules on contracts of the selected countries that guarantees the acceptance of autonomy therein.

Logically, any proposal for this amendment needs to take account of and correct the facts that have made the MC inadequate to consolidate autonomy. Thus, it must accept autonomy universally, make possible the enactment of other domestic rules needed to supplement it and respect, to a certain extent, the legal traditions of these jurisdictions. Likewise, this proposal needs to convince law makers that it promotes better laws than those in force. This conviction plays a fundamental role in the success of any attempt to amend laws since law makers are moved more by the desire of improving and updating laws than that of harmonizing them ${ }^{101}$. Hence, any successful proposal for a harmonious amendment of laws needs to be seen primarily as a proposal for sound law reform that will solve the problems and deficiencies of the law in force ${ }^{102}$.

A proposal for this harmonious conflict rules can be drafted in the form of a Model Law which fosters harmonization with flexibility by giving guidance as to the rules to be included in a national statute but, at the same time, allowing national legislator to modify them in accordance with national needs and circumstances ${ }^{103}$. Though, the harmonization attained through the enactment of a Model Law might be less satisfying than the unifica-

101 See, for example, the Exposés des Motifs of the Venezuelan PILA where harmonization is not mentioned in De Maekelt and Rondón (2002) pp. 137-149, and the Exposés des Motifs of the Peruvian CC where it is mentioned as a secondary goal of the bill in REVOREDO (1985) pp. 871-1038.

102 Garro (1992) pp. 612-613.

103 Parra-Aranguren (1988) pp. 50-51. 
tion attained with the enactment of an international convention. Where there is national reluctance to enact a convention, this reluctance might be circumvented by the enactment of domestic rules based on a Model Law that produces reasonable harmonization. Thus, this could be the way for consolidating autonomy in the selected countries. In fact, the successful role played by the 1985 UNCITRAL Model Law on International Commercial Arbitration in the enactment of arbitration laws in Latin America provides evidence that autonomy might be fostered by a Model Law ${ }^{104}$.

This Model Law on autonomy could be drafted within the CIDIP to be adopted by Latin American countries ${ }^{105}$. This option, though, seems rather unlikely since a CIDIP Model Law might meet the same failure as the MC. It seems that a Model Law to be adopted worldwide might be more attractive for these countries. Perhaps, a Model Law drafted by UNCITRAL could be more effective. Instruments drafted by UNCITRAL - the Arbitration Model Law and the CISG- have been widely adopted by Latin American countries and have succeeded in harmonizing their laws. Besides, the universal, rather than regional, scope of application of such a Model Law would lead to a wider harmonization on autonomy.

OHADAC, the Organization for the Harmonization of Commercial Law in the Caribbean Countries, has also recently prepared a Draft Model Law on Private International Law that contains rules on autonomy for commercial contracts modelled in the MC. This draft, if adopted by Caribbean countries, might also contribute to the consolidation of autonomy therein ${ }^{106}$.

The Hague Conference on Private International Law has conducted a study on the possibility of drafting an instrument on party autonomy for international contracts, to be adopted universally so as to foster further harmonization on autonomy. For the time being, the Conference has developed a set of non-binding global Principles on Choice of Law in International Commercial Contracts to serve as guidelines for parties, judges and arbitrators ${ }^{107}$. These Principles could be a useful tool for consolidating autonomy in Latin America if incorporated in national conflict laws ${ }^{108}$. Indeed, Paraguay has already incorporated them in its legislation widening its scope to all international contracts ${ }^{109}$.

In sum, either a Model Law or a set of General Principles might serve as guidelines for a harmonious amendment of domestic conflict rules on international contracts in Latin America and, specifically, in Brazil, Chile and Uruguay. The movement towards accepting autonomy initiated by the MC might be reinforced by an internationally negotiated instru-

\footnotetext{
104 The UNCITRAL Model Law on arbitration has been adopted with minor changes in Bolivia, Chile, Guatemala, Mexico, Paraguay, Peru and Venezuela and with more substantive changes in Brazil and Costa Rica. Further, it inspired the Mercosur Agreement on International Commercial Arbitration which has been ratified by Argentina, Brazil, Paraguay and Uruguay.

105 The methodology of drafting Model laws has been adopted by CIDIP VI and suggested as a way forward for future CIDIPS: FERNÁNDEZ (2002); VÁSQUEZ and RodAS (2002).

106 See OHADAC (2014)

107 See Hague Conference (2008) and (2015).

108 Brazil, Chile and Uruguay are members of the Hague Conference.

109 Law N 5393 of 2015.
} 
ment of a universal scope that helps to settle the opinion of national lawmakers in favour of autonomy.

\section{ADDITIONAL REQUIREMENTS FOR THE CONSOLIDATION OF AUTONOMY IN BRAZIL, CHILE AND URUGUAY}

Besides the enactment of conflict rules on autonomy, these jurisdictions will need to enact default rules for determining the governing law of a contract in the absence of choice by the parties. Ideally, these default rules should also be harmonious. Achieving a consensus in respect of them will require thorough negotiation and compromise since the law in force in these countries differs. In Brazil, it provides for the application of the law of the place of making of the contract. ${ }^{110}$ In Chile, it provides for the application of the law of the place of performance if they are to be performed in Chile or the law of the place of making if they are to be performed abroad. ${ }^{111}$ In Uruguay, it provides for the application of the law of the place of performance determined by the presumptions of the Treaty on International Civil law of Montevideo, 1889. ${ }^{112}$ Different default rules exist also in other Latin American countries where autonomy is already consolidated. ${ }^{113}$ In sum, enacting harmonious default rules for contracts in these countries would be difficult and might demand a substantial change in their legal tradition. The consolidation of autonomy in these jurisdictions might contribute to this harmonization; however, if this harmonization is not achieved, the sole acceptance of autonomy will diminish significantly juridical uncertainty for the contracting parties in them.

\section{CONCLUSIONS}

Party autonomy in international contracts is not statutorily accepted in some Latin American countries as Brazil, Chile and Uruguay, where national courts vacillate as to upholding choice of law clauses. These clauses, however, are regularly included in international contracts connected to them notwithstanding they are either not regulated, or rejected by their conflict rules. Additionally, these conflict rules differ significantly in determining the law governing international contracts. This causes juridical uncertainty and legal risks for the parties since the governing law of a contract might vary depending on the conflict rules of the forum where a dispute is brought.

There is consensus in accepting that the consolidation of autonomy will minimize these problems and help to harmonize conflict rules on contracts in Latin America. Thus, it will secure that choice of law clauses will be upheld irrespective of the jurisdiction where

\footnotetext{
110 Art. 9 ILCC.

111 Arts. 14, 16 Chilean CC; art. 113 Chilean CCom; Etcheberry (1960) pp. 55-60.

112 Art. 2399 Uruguayan CC.

113 Arts. 2652-2653 Argentinian CC; art. 2095 Peruvian CC; art. 30 Guatemalan Decree 2-89, art. 13 V Mexican Federal CC and art. 74 Panamanian CPIL; art. 60 Dominican Republic PILA, art. 11 Paraguayan Law 5393, art. 30 Venezuelan PILA.
} 
proceedings are brought, will permit the parties to anticipate with reasonable certainty the law that will govern their contracts and will allow them to avoid inappropriate governing laws for them.

Several attempts to produce this consolidation, however, have had limited effect. Hence, OAS' countries drafted the MC with this purpose, but it has only been ratified by Mexico and Venezuela, and other ratifications might not take place.

Three reasons could explain the failure of the MC in attracting more ratifications. First, the MC has too restricted a scope of application and lacks universality. Thus, where it is enacted, international contracts are necessarily submitted to a double legal regime: that of the MC, for contracts linked to at least two Latin American State parties, and that of other conflict rules, for all other contracts. Hence, even if it were enacted in all jurisdictions, the acceptance of autonomy and the harmonization of rules on contracts within Latin America would not be achieved unless each jurisdiction enacts other conflict rules in harmony with those of the MC. Second, the implementation of the MC requires that every ratifying country has adequate conflict rules to supplement it when it refers certain issues to national laws or leaves legal gaps to be filled in. These rules are equally needed for contracts outside its scope of application. But several Latin America countries have no rules on these issues, and Third, the MC conflicts with the legal tradition of some countries reluctant to amend their legislation.

Thus, the consolidation of autonomy and the harmonizing amendment of the conflict rules on contracts in Latin America is pending. National lawmakers might be moved to make this amendment by the lobby of legal practitioners who are including choice of law clauses in international contracts and courts who are beginning to accept these clauses in some cases. Further, this amendment might be fostered by a flexible non-binding international instrument, such as a Model Law or a set of Principles, that includes rules on autonomy widely accepted in comparative law but adaptable to national needs and legal tradition.

\section{BIBLIOGRAPHY}

Albornoz, Mercedes (2009): "El Derecho Aplicable a los Contratos Internacionales en los Estados del Mercosur", Boletín Mexicano de Derecho Comparado, № 125: pp. 631-666.

Boggiano, Antonio (1993): "Study on International Contracts Requested by The Organization of American States", in OAS/Ser. K/XXI.5, CIDIP-V/doc.9/93, 29-X-1993 pp. $1-125$.

Boggiano, Antonio (1995): Contratos Internacionales (Depalma, Buenos Aires, second edition).

Boggiano, Antonio (1996): "La Convention Interaméricaine sur la Loi Applicable aux Contrats Internationaux et les Principes d'UNIDROIT", Uniform Law Review, $\mathrm{N}^{\circ} 1$ : pp. 219-228.

Convention on the Law Applicable to Contractual Obligations, Rome (19 June 1980). 
Convention on the Law Applicable to Contracts for the International Sale of Goods, The Hague (22 December 1986).

Burman, Harold (1995): "International Conflict of Laws, The 1994 Inter-American Convention on the Law Applicable to International Contracts, and Trends for the 1990s", Vanderbilt Journal of Transnational Law, vol. 28, No 2: pp. 367-387.

Bustamante I Rivero, José (1942): El Tratado de Derecho Civil Internacional de 1940 (Montevideo).

Economic Commission for Latin America, ECLA (2017): 2016 Statistical Yearbook for Latin America and the Caribbean (United Nations, CEPAL).

De Araujo, Nadia (1998): "A Convenção do México sobre o Direito Aplicável aos Contratos Internacionais: suas Características e Influência para o Direito Internacional Privado Brasileiro" in Casella, Paolo (coord.), Integração Jurídica Interamericana: as Convenções Interamericanas de Direito Internacional Privado (CIDIPs) e o Direito Brasileiro (São Paulo, LTr Ed.) pp. 435-457.

De Araujo, Nadia (2002): "Contratos Internacionais e a Jurisprudência Brasileira: Lei Aplicável, Ordem Pública e Cláusula de Eleição de Foro”, in RodAs, João (coord.), Contratos Internacionais (São Paulo, Ed. Revista dos Tribunais, third edition) pp. 195-229.

De Araujo, Nadia and Corrêa, Daniela (2008): "Contratos Internacionais no Brasil: Posicão Atual da Jurisprudencia no Brasil”, Revista Trimestral de Direito Civil, No 34: pp. 267-280.

De Maeklt, Tatiana (2001): "La Flexibilización del Contrato Internacional en la Convención Interamericana sobre Derecho Aplicable a los Contratos Internacionales", in Ley de Derecho Internacional Privado de 6 de Agosto de 1998. Libro Homenaje a Gonzalo Parra-Aranguren, vol. II (Caracas, Tribunal Supremo de Justicia) pp. 359-380.

De Maeklt, Tatiana and Rondón, Hildegard (2002): Ley Venezolana de Derecho Internacional Privado. Tres Años de su Vigencia (Caracas, Academia de Ciencias Políticas y Sociales).

Etcheberry, Alfredo (1960): Bilateral Studies in Private International Law: American-Chilean Private International Law, $n^{\circ} 10$ (New York, Oceana Publications).

Feldstein, Sara (2000): Derecho Internacional Privado (Buenos Aires, Ed. Universitaria).

Fernández, Diego (1994): La Codificación del Derecho Internacional Privado en América Latina (Madrid, Edit. Beramar).

Fernández, Diego (1995): "La Convention Interaméricaine sur la Loi Applicable aux Contrats Internationaux: certain Chemins Conduisent au-delà de Rome", Revue Critique de Droit International Privé, vol. 84, Nº1: pp. 178-186.

Fernández, Diego (2002) “The Present and Future of CIDIP”. Available in www.oas.org/ dil/PrivateIntLaw-BasicProblem-Eng.htm. Date of visit: 27 December 2017.

Garro, Alejandro (1992): "Unification and Harmonization of Private International Law in Latin America”, The American Journal of Comparative Law, vol. 40: pp. 587-633.

Giuliano, Mario and Lagarde, Paul (1980): "Report on the Convention on the Law Applicable to Contractual Obligations", Official Journal of the European Community, $\mathrm{N}^{\circ} \mathrm{C}$ 282, 31-X-1980: pp. 1-46.

Griffith, Paul (1959): American-Brazilian Private International Law. Bilateral Studies in Private International Law, no 9 (New York, Oceana Publication). 
Guzmán, Alejandro (1982): Andrés Bello Codificador. Historia de la Fijación y Codificación del Derecho Civil en Chile, vol. I (Santiago of Chile, Edit. de la Universidad de Chile).

Hague Conference on Private International Law (2008): "Feasibility Study on the Choice of Law in International Contracts. Report on Work Carried Out and Conclusions (Follow-up Note)", Prel. Doc. No5, II-2008.

Hague Conference on Private International LaW (2009): "Feasibility Study on the Choice of Law in International Contracts. Report on Work Carried Out and Suggested Work Programme for the Development of a Future Instrument", Prel. Doc. No7, III-2009.

Hague Conference on Private International Law (2015): "Principles on Choice of Law in International Commercial Contracts", 19 March 2015.

Herbert, Ronald (1994): "La Convención Interamericana sobre Derecho Aplicable a los Contratos Internacionales", Revista Uruguaya de Derecho Internacional Privado, No 1: pp. 45-62.

Hernández-Bretón, Eugenio (2001): "Las Obligaciones Convencionales en la Ley de Derecho Internacional Privado" in Ley de Derecho Internacional Privado de 6 de Agosto de 1998. Libro Homenaje a Gonzalo Parra-Aranguren, vol. II (Caracas, Tribunal Supremo de Justicia) pp. 325-341.

Hernández-Bretón, Eugenio (2003): "Autonomía Conflictual en América Latina. Tendencias Actuales", Anuario Hispano-Luso-Americano de Derecho Internacional, vol. 16: pp. 441-471.

Hernández-Bretón, Eugenio (2005): "Propuesta de Actualización de los Sistemas Latinoamericanos de Contratación Internacional”, ELDial.com, $\mathrm{N}^{\circ}$ 6: pp. 1-23. Available in http://www.eldial.com/suplementos/Privado/doctrina/ip050624-c.asp. Date of visit: 27 December 2017.

Hook, Maria (2016): The Choice of Law Contract (Oxford, Hart Publishing).

Inter-American Convention on the Law Applicable to International Contracts, Mexico (17 March 1994).

Juenger, Friedrich (1994): "The Inter-American Convention on the Law Applicable to International Contracts: Some Highlights and Comparisons", The American Journal of Comparative Law, vol. 42: pp. 381- 393.

Juenger, Friedrich (1997): "Contract Choice of Law in the Americas", The American Journal of Comparative Law, vol. 45: pp. 195-208.

Kassis, Antoine (1993): Le Nouveau Droit Européen des Contrats Internationaux (Paris, L.G.D.J).

Lando, Ole (1976): International Encyclopedia of Comparative Law. vol. III, ch. 24 (The Hague, Mouton).

Lando, Ole (1985): "The Conflict of Laws of Contracts. General Principles" in Académie de Droit International, Recueil des Cours, vol. 189: pp. 229-447.

Lando, Ole (1996-97): "Some Issues Relating to the Law Applicable to Contractual Obligations”, The King's College Law Journal, vol. 7 pp. 55-74.

LeÓn, Avelino (2002): "Reforma del Sistema Chileno de Derecho Internacional Privado" in Kleinheisterkamp, Jan (coord.), Avances del Derecho Internacional Privado en América Latina: Liber Amicorum Jürgen Samtleben. Max-Planck-Institut für ausländisches und internationales Privatrecht (Montevideo, Fundación de Cultura Univ.) pp. 179-189. 
LeYva, José (1998): "La Convención Interamericana sobre el Derecho Aplicable a los Contratos Internacionales", Revista Jurídica del Perú, N 1: pp. 315-329.

Mayer, Pierre and Heuzé, Vincent (2004): Droit International Privé (Paris, LGDJ, eighth edition).

Nygh, Peter (1999): Autonomy in International Contracts (Oxford, Clarendon Press).

Noodt, María (1997): "Convención Interamericana sobre Derecho Aplicable a los Contratos Internacionales", in El Derecho Internacional Privado Interamericano en el Umbral del Siglo XXI. Sextas Jornadas de Profesores de Derecho Internacional Privado, Segovia 1-2 Diciembre 1995 (Madrid, Eurolex) pp. 90-134.

OHadaC Draft Model Law on Private International Law, 2014. Available in http:// www.ohadac.com/textes/5/86/titulo-i-disposiciones-comunes.html. Date of visit: 10 January 2017.

Organization of AMERICAN STATES:

- OAS CP/Res. 486 (717/87), 23-X-1987,

- CIDIP IVIRes. 2/89, Final Act,

- OAS/Ser. K/XXI.5, CIDIP-VIdoc.9/93, 29-X-1993,

- OAS/Ser.KIXXI.5, CIDIP-VI10/93, 30-XII-1993,

- OEA/Ser. KIXXI.5, CIDIP-VI 11/93, 30-XII-1993,

- OEA/Ser. K/XXI.5, CIDIP-V/12/93, 28-XII-1993,

- OEA/Ser. KIXXI.5, CIDIP-V/14/93, 30-XII-1993.

- OEA/Ser. K/XXI.5, CIDIP-V/15/93, 23-XII-1993,

- OEA/Ser. KIXXI.5, CIDIP-VIdoc. 32/94 rev. 1,18-III-1994,

- OEA/Ser.K/XXI.5, CIDIP-VIDoc. 46/94, vol. I and II, 25-I-1996.

Opertti, Didier (1994): "La CIDIP V, una Visión en Perspectiva”, Revista Uruguaya de Derecho Internacional Privado $\mathrm{N}^{\circ} 1$ : pp. 11-43.

Opertti, Didier and Fresnedo, Cecilia (1997): Contratos Comerciales Internacionales (Montevideo, Fundación de Cultura Universitaria).

Parra-Aranguren, Gonzalo (1988): "General Course of Private International Law: Selected Problems", Académie de Droit International, Recueil des Cours, vol. 3: pp. 9-224.

Parra-Aranguren, Gonzalo (1994): "La Quinta Conferencia Especializada Interamericana sobre Derecho Internacional Privado (CIDIP V, México, 1994)", Revista de la Fundación Procuraduría General de la República, No 11: pp. 179-247.

Parra-Aranguren, Gonzalo (1996): “The Fith Inter-American Specialized Conference on Private International Law”, in Borrás, Alegría et al. (edit.), E Pluribus Unum. Liber Amicorum George A. L. Droz (The Hague, Kluwer Law International) pp. 299-320.

Pereznieto, Leonel and Silva, Jorge (2000): Derecho Internacional Privado. Parte Especial (Mexico D.F., Oxford University Press).

Plender, Richard and Wilderspin, Michael (2001): The European Contracts Convention (London, Sweet and Maxwell, second edition). 
Posenato, Naiara (2006): "O Princípio da Autonomia da Vontade na Convenção do México de 1994" in Contratos Internacionais, Tendências e Perspectivas (Ijuí, Ed. Unijuí) pp. $19-85$.

Reichsteiner, Beat (2002): Direito Internacional Privado. Teoria e Prática (São Paulo, Saraiva, fifth edition).

Revoredo, Delia (1985): Código Civil VI. Exposición de Motivos y Comentarios. Derecho Internacional Privado (Lima, Okura Editores S.A.).

Samtleben, Jurgen (1979): "El Territorialismo de Leyes en América Latina”, in Pereznieto, Leonel and Belair, Claude (edit.), Primer Seminario Nacional de Derecho Internacional Privado (México D.F., UNAM) pp. 173-209.

Samtleben, Jurgen (1983): Derecho Internacional Privado en América Latina. Teoría y Práctica del Código de Bustamante, vol. I (trad. Carlos Bueno-Guzmán, Buenos Aires, Depal$\mathrm{ma})$.

Samtleben, Jurgen (1984): "Teixeira de Freitas e a Autonomia das Partes no Direito Internacional Privado Latino-Americano”, Scientia Juridica, No 33: pp. 343-366.

Samtleben, Jurgen (1987): "La Relación entre Derecho Internacional Público y Privado en Andrés Bello", in Andrés Bello y el Derecho Latinoamericano (Caracas, La Casa de Bello) pp. 159-169.

Samtleben, Jurgen (2002): "El Enigma del Artículo 30 de la Ley de Derecho Internacional Privado", in Libro Homenaje a Gonzalo Parra-Aranguren. Addendum 2001 (Caracas, Tribunal Supremo de Justicia) pp. 355-371.

Santos, Rubén (1998): El Derecho Aplicable a los Contratos Internacionales: con Especial Referencia al Contrato de Transferencia de Tecnología (Montevideo, Fundación de Cultura Univ., second edition).

Scoles, Eugene, Hay, Peter, Borchers, Patrick and Symeonides, Symeon (2004): Conflict of Laws (St Paul Minnesota, Thomson West, fourth edition).

Strenger, Irineu (1967): Da Autonomia da Vontade em Direito Internacional Privado (São Paulo).

Strenger, Irineu (1996): Direito Internacional Privado (São Paulo, Ed. LTR, third edition). Tratados de Montevideo 1889 (1894): Actas de Sesiones del Congreso Sud-Americano de Derecho Internacional Privado Instalado en Montevideo del 25 de Agosto de 1888 y Clausurado el 18 de Febrero de 1889 (Buenos Aires, Taller Tipográfico de la Penitenciaría Nacional).

Tratados de Montevideo 1940 (1940): Segundo Congreso Sudamericano de Derecho Internacional Privado, de Montevideo (Buenos Aires, Rep. Argentina Ministerio de Relaciones Exteriores).

Treaty for the Constitution of a Common Market, MerCOSUR, Asunción (26 March 1991).

Treaty on International Civil LaW, Montevideo (12 February 1889).

Uncitral Model LaW on International Commercial Arbitration, Vienna (21 June 1985)

United Nations Convention on Contracts for the International Sale of Goods, Vienna (11 April 1980) 
ValladÃo, Haroldo (1952): "Le Droit International Privé des Etats Americains" Académie de Droit International, Recueil des Cours, vol. II: pp. 5-115.

ValladĀo, Haroldo (1974): Direito Internacional Privado (Rio de Janeiro, Freitas Bastos, fourth edition).

ValladÃo, Haroldo (1987): Derecho Internacional Privado (México D.F., Edit. Trillas).

VÁsquez, Manuel and Rodas, João (2002): "CIDIP VII y Etapas Sucesivas". Available in: http://www.oas.org/dil/esp/derecho_internacional_privado_conferencias.htm. Date of visit: 31 January 2018.

Vial, María Ignacia (2013): "La Autonomía de la Voluntad en la Legislación Chilena de Derecho Internacional Privado", Revista Chilena de Derecho, vol. 40, N 3: pp. 891-927.

Villarroel, Carlos and Villarroel, Gabriel (2015): Derecho Internacional Privado (Santiago, Editorial Jurídica de Chile).

\section{TABLE OF LEGISLATION}

- Argentinian Civil Code, Law 26.994 (8/10/2014).

- Brazilian Introductory Law to the Civil Code, Law-Decree 4.657 (9/9/1942).

- Brazilian Law 9.307 (24/09/1996), Arbitration Law.

- Chilean Civil Code (14/12/1855).

- Chilean Commercial Code (23/11/1865).

- Chilean Law 19.971 (29/09/2004), on International Commercial Arbitration.

- Chilean LaW-Decree 2.349 (28/10/1978).

- Cuban Civil Code, Law 59 (15/10/1987).

- Dominican Republic Private International Law Act, Law 544-14 (18/12/2014).

- Guatemalan Decree 2-89 (18/03/1989), Law of the Judicial Organ.

- Mexican Civil Code for the D.F. (25/05/2000).

- Mexican Civil Code on Federal Matters (7/01/1988).

- Panamanian Code of Private International Law, Law 7 (8/05/2014)

- Paraguayan Law 5.393 (20/01/2015), on the Law Applicable to International Contracts.

- Peruvian Civil Code, Law-Decree 295 (25/08/1984).

- Regulation (EC) No 593/2008 of the European Parliament and of the Council of 17 June 2008 on the law applicable to contractual obligations (Rome I) (4/07/2008).

- Uruguayan Civil Code, Law 10.084 (12/12/1941).

- Uruguayan General Procedural Code, Law 15.982 (14/11/1988)

- Venezuelan Private International Law Act (6/08/1998). 